\title{
CRITICAL REVIEW OF TAMAKA SHAWASA (ASTHMA) CHIKITSA
}

\author{
Amit Kapila ${ }^{1}$, Amnish Verma ${ }^{2}$, Rajni Bhardwaj ${ }^{3}$, Amandeep Sharma ${ }^{4}$ \\ ${ }^{1}$ Assistant Professor, Department of Rasashastra \& Bhaishajyakalpana, Desh Bhagat Ayurvedic College \& Hospital, \\ Mandi Gobindgarh, Punjab.
}

${ }^{2}$ Reader, PG Department of Rasashastra \& Bhaishajyakalpana, Desh Bhagat University, Mandigobingarh. Punjab.

${ }^{3}$ Assistant Professor, Department of Rasashastra \& Bhaishajya Kalpana. Desh Bhagat Ayurvedic College \& Hospital Desh Bhagat University, Mandi Gobindgarh (Punjab).

${ }^{4}$ Assistant Professor, Department of Agad Tantra, Desh Bhagat Ayurvedic College \& Hospital, Mandi Gobindgarh, Punjab.

Conflicts of Interest: Nil

Corresponding author: Amit Kapila

ABSTRACT

Asthma is known as reactive airway disease. This hyperresponsiveness manifests itself as bronchoconstriction following exercise, on natural exposure to strong as irritant fumes such as sulphur dioxide, tobacco smoke or cold air and an intentional exposure in the laboratory to inhalations of histamine or parasympathamimetic agent such as methacholine. In Ayurveda it can be correlated with Tamaka Shwasa. Tamaka Shwasa is one of the diseases where Nidana parivarjana and samprati vighatana plays an important role. The detailed study of Nidana panchaka is helpful in better understanding of the disease and for the proper treatment. As Kapha and Vata are the pre-dominant Doshas, so the medicines and the dietetic regimen which controls the Kapha and Vata due to their Ushna guna and are Vata- anulomaka in action must be utilized in the treatment of Shwasa roga. While The patient with Kapha and Vata dominance and of strong build should be given Samshodhan therapy i.e. vaman \& Virechana.

Keywords: Tamaka Shwasa, Shwasa roga, Samshodhana, Asthma.

\section{INTRODUCTION}

Tamaka Shwasa is one of the five verities of Shwasa roga, explained in almost all the classics of Ayurveda. The term 'Tamaka Shwasa' consists of two words Tamaka and Shwasa. The word Tamaka' is derived from the dhatu (root) Tamu - glanou with 'kwip' pratyaya (syllable). It means to choke, be suffocated, darkness. ' 'Tamyati iti Tamaka'Tama eva Tamaka' i.e. where Tama occurs is Tamaka. ${ }^{2}$ Tama means Darkness. The word 'Shwasa' is derived from the dhatu 'shwas' with 'ghai' pratyaya. 'Shwasti iti Shwasah' it means to breathe, by which the respiratory movements take place. ${ }^{3}$ The term Tamakaswasa is formed by Karmadharaya samasa as "Tamakascha asauShwasascha Tamaka Shwasaha" It means difficulty in breathing, which mainly occurs during night time. Sushruta defined TamakaShwasa as "Visheshad durdine tamyeti shwashasa tamako matah". ${ }^{4}$ The attack of Shwasa with tamapravesha occurs specially during Durdina. No commentator has mentioned the meaning of the word Durdina. Acharya Charaka explained that Tamaka Shwasa gets aggravated when one is exposed to cloudy atmosphere, cold water, cold weather, and wind blowing from eastern direction, Kapha aggravating food and regimen. ${ }^{5}$ Hence the above conditions can be correlated with Durdina. Vijayarakshita the commentator of Madhava Nidana explained as "Shwasastu bastrikadmana samavatordhwa gamitha iti" i.e. in Shwasa roga the expired air produces sound similar to the sound of below of blacksmith. ${ }^{6}$ TamakaShwasa has vitiation of Kapha \& Vata and it is pittasthana (amashaya) samudbhava vyadhi. $^{7}$ Therefore, our treatment should be aimed to pacify the vitiated Vata and Kapha Dosha along with Nidana parivarjana. Acharya Charaka has given the guidance for better management of TamakaShwasa i.e shodhana followed by shamana Chikitsa, should be done in Balavan and Kaphadika patients, where as shamana and tarpana should be done in Durbala and Vatadhika patients. As it is an episodic disease and yapya it is difficult to cure. So before starting the treatment, special attention has to be given, for detail examination of the children, to know Rogibala and Rogabala. The general line of treatment I s Nidana parivarjana, Samshodhansa and shamshamana. 
(1) NIDANA PARIVARJANA: Nidana, Dosha and dushya are the essential factors in the of disease process. Anubandha and Ananubandha of these three factors influence in the ocurence of signs and symptoms of disease. ${ }^{8}$ That is why acharya Charaka has given much importance for the Nidana parivarjana in hikka and Shwasaroga. It is said that if the person suffering from the Shwasa wants the healthy condition (Arogya) he must avoid the Nidana factors. Acharya Sushruta stressing for the Nidana parivarjana explained as "sankshepatahkriyayogo Nidana parivarjanam"." However but avoiding the causative factors may be difficult in children because they are more susceptible for allergens, upper respiratory tract infections, dust and exercise during play works and many are allergic to variety of foods etc. Avoiding these causative factors may reduce frequency of attacks in children. As the Tamaka Shwasa is yapya in nature, proper advises should be given to both children and parents regarding the Nidana parivarjana. $^{10}$

\section{Avoidance of Triggers / Aggrevators}

Physical Factors: The physical factors, which can cause symptoms in asthmatic children, are exercise, strong smell, cold air, changes in weather etc. In majority of cases the patient or parents easily identify these factors. For the better management of asthmatic children, it is necessary to avoid the exposure to these factors.

(a) Allergens: Aero-allerges are important triggers of attack in most allergic asthmatics. The child may get severe disease if the child had been exposed to allergen within first year of life. Most of the allergens include dust, mites, moulds, pollens and animal proteins. Now house dust mite (dead or alive) claimed to be the important cause for nocturnal symptoms. Particular care should be taken for the children who are having family history of allergy, because these children are susceptible for allergic disorders. Therefore, avoidance of allergens plays an important role. Recommendations for reducing allergen

- The humidity in houses should be minimized by good ventilation.

- All the bedding (mattresses, pillow etc) which is washable should be washed regularly with hot water.

- Pillow and bed is to be covered with mite proof covers.

- Woollen clothing's and bedding are better to avoid because they may harbour dust and house dust mite. Carpets in the bedroom are better to remove.

- Whenever practical, bedding should be exposed to the sun which kills mites.

(b) Rhinitis / Sinusitis: When the child is having repeated attacks of rhinitis or sinusitis or otitis then a prompt treatment should be advocated. Always enquiry is must to know the history of nasal obstruction, sneezing, snoring, night cough, interrupted sleep and gastric reflux (heartburn). If present, then best solution would be avoidance of causative factors and adequate treatment of these conditions.

Tamaka Shwasa patients can be grossly divided into two categories.

- Kaphadhika and balavana

- Durbala and Vatadhika.

In the prior category Shodhana can be adopted and Shamana in the later where as Nidana parivarjana is mandatory in both categories

2) SAMSHODHANSA: Great importance has been given for the Shodhana karma in the management of Shwasa, which helps in eliminating the vitiated Doshas from the body. Vamana, virechana and nasya are advised to adopt for Tamaka Shwasa Chikitsa.

\section{a) Deepana And Pachana}

It is said that "Rogah sarve api managanow"." Agnimandya and ama play an important role in the production of T.S. Hence in order to normalize the Agni and to remove ama, deepana and pachana should be given first. ${ }^{12}$

b) Poorva Karma: Abhyanta snehapana should be done with judicious use of medicated ghee or oil till the Samyaka Snigdha Laxanas appear. Then abhyanga and swedana should be done. Vishrama kala should be decided according to Shodhana (Vamana /Virechana).

c) Snehan swedana : Here the til tail and saindhava lavana should be gently massaged on chest and back. Then Nadi / Prastra / Sankara Swedana should be given to loosen the sticky and tenacious sputum from the Pranavaha shrotas for the easy flow of Pranavayu.

(c) Vamana: Dalhana commentator of sushruta says that "Shleshmabhuyistha Tamakah" i.e. Tamaka Shwasa is Kapha predominant disease. Hence vamana will be helpful for the patients. Vamana should be done in balavana (having good 
strength) and Kaphadhika (having more Kapha) patients and it is also indicated in patients suffering from the Kasa and Swarabhanga.

(d) Virechana: After Vamana Virechana should be administered in balavana and Kaphadika patients, and it should be followed by Patya Ahara, Vihara, Dhoomapana, Leha and Shamana Chikista. In Tamaka Shwasa patient's virechana should be given with Vatashleshmahara dravyas. According to Vagbhata, in cases of Admana, Udavarta and Tamaka Shwasa first anulomana should be done with rice-mess mixed with matulunga, amlavetasa, hingu, pilu and bida. Then Virechana with drugs mixed with Saindhava and any sour fruit followed by warm water should be administered.

3) SHAMANA CHIKITSA: Shamana involves the usage of a strict patya patya, dhoomapana, leha etc. Kshara leha"s should be used only when there is Kaphadhikya, which is obstructing the pranavara srotas. Tarpana should be done with Sneha, Yusha And Mamsa Rasa along with Vatanashaka drugs, in cases like Vatadhika, durbala, bala and vriddha (aged). Drugs, foods and drinks having Ushna guna, which acts as Kapha Vatagna and Vatanulomana, should be administered to the Tamaka Shwasa patient. ${ }^{13}$ The vitiated Doshas can be treated with following methods of treatments.

1. Vatakara and Kaphahara chikista

2. Kaphakara and Vatahara chikista

3. Single sided treatments like Kaphahara but Vatakara Vatahara but Kaphakara should not be done in any cases.

4. Out of all the Vatahara treatment is better.
In all cases of Shwasa if brimhana is done, then the Shwasa becomes prataha sukhasadhya even though it is associated with upadravas. In the same if shamana treatment is adopted then it is always sukhasadhya for treatment. If karshana treatment is adopted, then Shwasa roga becomes asadhya for treatment. Brinhana is not a complete treatment so it should be done with shamana Chikitsa but karshana therapy should not be advised especially in case of children.

\section{TREATMENT ACCORDING DOSHA PREDOMINANCE}

In Vatapittanubandhi Suvarchala swarasa, milk, ghee and Trikatu choorna are to be taken along with Anupana of Shali odana. In Kaphapittanubandhi patients Shirisha pushpa

swarasa or saptaparna swarasa along with pippali and madhu should be administered. In Kaphadhika patients, if Kapha is obstructing the pranavaha srotas then kshara lehas like ashwagandha kshara along with honey \& ghee etc should be administered. ${ }^{14}$

(a) Anupana : According to the disease the anupana has been mentioned in Yogaratnakara ${ }^{15}$ For Shwasa brimhadadi and Shunti is anupana.

(b) Patya and Apatya: Along with Nidana parivarjana and Chikitsa, proper dietetic and seasonal regimens are necessary things to be followed. By that one can prevent the attacks of Tamaka Shwasa. Seasonal variations and climatic \& atmospheric changes will always complicate the management of TamakaShwasa where nothing can be much expected. But dietetics and mode of life can be adopted according to the disease. Thus patyapatya helps in getting a healthy life.

Table 3: Showing (A) Pathya (B) Apathya For Shwasa. ${ }^{16}$

\begin{tabular}{|c|c|c|c|c|c|}
\hline \multicolumn{3}{|l|}{ PATYA } & \multicolumn{3}{|l|}{ APATHYA } \\
\hline AHARAS & Y.R & B.R & AHARAS & Y.R & B.R \\
\hline Rakta shali & + & + & Rooksha anna pana & + & + \\
\hline Kulattha & - & - & Sheetanna pana & + & + \\
\hline Godhooma & + & + & Guru anna pana & + & + \\
\hline Yava & + & + & Vidahi anna pana & - & + \\
\hline Tandula & + & + & Vishtambi padartha & t & \\
\hline Puratana sarpi & + & - & Sevana & - & + \\
\hline Madhu & + & + & Mahisha Dugdha & + & + \\
\hline Aja paya & + & + & Masha & - & + \\
\hline Sura & + & + & Kanda & + & + \\
\hline Patola & + & + & Sarshapa & + & + \\
\hline Varthaka & + & + & Dushta ambu & + & + \\
\hline Rasona & + & + & Tailabrishta nishpava & - & + \\
\hline
\end{tabular}




\begin{tabular}{|c|c|c|c|c|c|}
\hline Bimbi phala & + & + & Sheshmakaraka ahara & - & + \\
\hline Jambeera & + & + & Anupana & - & + \\
\hline Tanduleeya & + & + & Mamsa varga & & \\
\hline Vastuka & + & + & Anupa mamsa & - & + \\
\hline Jeevanthi & - & + & Matsya & + & + \\
\hline Kamala moola & - & + & Viharaja & & \\
\hline KaphaVata nashaka & + & + & Mootra vegavarodha & + & + \\
\hline Annapana & 7 & & Udgar vegavarodha & + & + \\
\hline Matulunga & - & + & Trishna veghavarodha & + & + \\
\hline Ushnajala & + & + & Kasa veghavarodha & + & + \\
\hline Shasha mamsa & + & + & Adwagamana & - & + \\
\hline Ahita bhuk & - & + & Bharavahana & - & + \\
\hline Tittira & + & + & Renava soorya padu & - & + \\
\hline Lava & + & + & PoorvaVata & + & + \\
\hline Daksha & + & + & Danta dhavana & + & + \\
\hline Shuka & + & + & Shrama & + & + \\
\hline Dhavadvijamriga & + & + & Kama & - & + \\
\hline Aushadhi Varga & 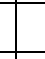 & . & Upacharaja & & 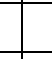 \\
\hline Draksha & + & + & Raktamokshana & + & + \\
\hline Ela & + & + & Nasya & + & + \\
\hline Trikatu & - & + & Basti & + & + \\
\hline Gomutra & + & + & & & \\
\hline Kantakari & + & + & & & \\
\hline \multicolumn{6}{|l|}{ Viharaj } \\
\hline Divaswapna & + & + & & & \\
\hline Vamana & + & + & & & \\
\hline Swedana & + & + & & & \\
\hline Dhoomapana & + & + & & & \\
\hline
\end{tabular}

\section{DISCUSSION:}

Acharya Charaka has explained Shwasa as Pittasthana Samudbava vyadhi. ${ }^{17}$ Vagbhata and chakrapani have explained it as Amashaya samydbhava vyadhi. All etiological factors including Agnimandyakaraka and Amotpadaka Nidanas may be grouped under this heading. These factors affect pittasthana, which may result in Agnimandya and ama formation. It is explained that "Rogah sarve apimandagnow" i.e. all the diseases are produced by Mandagni. Acharya Charaka explained that the Kapha along with vayu obstructs the srotas. This obstructed vayu trying to overcome the obstruction moves in all directions resulting in Shwasa. ${ }^{18}$ Here the term "Kapha purvaka" is commented by chakrapani as Kapha pradhana ie predominance of Kapha. ${ }^{19}$ It is important to note that the assessment of the Dosha is essential while treating the disease. Vata and Kapha are contrary to each other. In the management of Tamaka Swasa, it is customary to note that when Vata is obstructed by Kapha, just by increasing Vata, Kapha will automatically alleviate and Vata will be free to move in its course. When Vata is much aggravated than Kapha, treatment to increase Kapha will help to correct Vata. The antagonistic property of Vata and Kapha is a physiological phenomenon, after correction of this imbalance; the Swasa roga can be relieved. To achieve the balance of Dosha, the Doshas, Vata and Kapha should be treated simultaneously. Vata Dosha plays an important role in the samprapti of Tamaka Swasa; hence Vata Shmana Chikitsa is always preferable. ${ }^{20}$

\section{Tamketu Virechana:}

Shwasa roga originates from the pitta sthana and the site of its expression is uraha Pradesh. Here Dosha involvement is of Kapha \& Vata. The pratiloma gati of vayu must be brought to anulomana. The pitta sthana disturbance leads to indigestion \& production of Aama Dosha which is the cause of production of vikrut Kapha Dosha. So it is of prime importance to treat the root cause of Shwasa roga i. e. pitta sthana. Hence virechana is 
the main treatment to eliminate the dusta pitta. For Vata anulaomana, virechana is equally effective. The patient with Weak constitution or durbala in prakruti like aged and childrens should be given brumahana and shamana therapy. In this tarpana, Sneha, Yusha, and Mamsa rasa are advocated. ${ }^{21}$

\section{CONCLUSION:}

In Ayurveda avoidance of causative factors is first line of treatment for any diseases. Tamaka Swasa is a Vata Kapha Pradhan Vyadhi, In the management of Tamaka Swasa, when Vata is obstructed by Kapha, just by increasing Vata, Kapha will automatically alleviate and Vata will be free to move in its course. When Vata is much aggravated than Kapha, treatment to increase Kapha will help to correct Vata. Charaka samhita emphasized that patient having good Aturabala with the dominance of Kapha should be treated with Vamana and Virechana therapy.

\section{REFERENCES.}

1. Raja RadhaKanta Deva; ShabdaKalpadrum, 3rdEdition, Chaukamba Sanskrit Series Office, Varanasi, Part II, pp. 590, Part IV, pp. 178-179.

2. Apte V.S. (1985), The Students Sanskrit English Dictionary, Shatilal Jain, Delhi.

3. Raja RadhaKanta Deva; ShabdaKalpadrum, 3rdEdition, Chaukamba Sanskrit Series Office Varanasi, Part II, pp. 590, Part IV, pp. 178179

4. Sushruta, SushrutaSamhita Ayurveda TattvaSandipika, Hindi Commentary Su. U. 51/8, 11thEdition, 1997. Editor, Kaviraja Ambikadutta Shastri, Chaukamba Sanskrit Bhavana, Part II, pp. 372 to382.

5. Agnivesha (2000), Charakasamhita with English Translation by Bhagwandasha R.K. Sharma), Volume IV, II Edition, Chi. 17/62, Chowkamba Sanskrit Series Office, Varanashi, pp. 117-125.

6. Madhavakar, Madhava Nidana, Madhukosha Sanskrit Commentary with Vidyotini Hindi Commentary Part II, Edtr. Prof. YadunandanaUpadhayaya. M.Ni. 12/12, 25th Edition, 1995, pp. 388, Part I 281, 289- 293

7. BrahmanandTripathi (1999), AstangaHridaya, Nirmal Hindi Commentary, Nidan sthan 4/9, 1st Edition, Edr. BramhanandTripathi, Chaukamba Sanskrit Pratisthana, Delhi, pp. 455 to 458,609 to 616 .

8. Madhavakar, Madhava Nidana, Madhukosha Sanskrit Commentary with Vidyotini Hindi Commentary Part II, Edtr. Prof.
YadunandanaUpadhayaya. Chapter 1/8, 25th Edition, 1995, pp. 388, Part I 281, 289, 290, 291, 292, 293-301

9. Sushruta, SushrutaSamhita Ayurveda Tattva Sandipika, Hindi Commentary, 11thEdition, 1997. Editor, KavirajaAmbikaduttaShastri, Uttarsthan 51, Chaukamba Sanskrit Bhavana, Part II, pp. 372 to382.

10. BrahmanandTripathi (1999), AstangaHridaya, Nirmal Hindi Commentary, 1st Edition, Edr. BramhanandTripathi, Nidana sthana 4/8, Chaukamba Sanskrit Pratisthana, Delhi, pp. 455 to 458,609 to 616 .

11. Agnivesha (2000), Charakasamhita with English Translation by Bhagwandasha R.K. Sharma), Chikitsa sthana 17/63, Volume IV, II Edition, Chowkamba Sanskrit Series Office, Varanashi, pp. 117-125.

12. Agnivesha (2000), Charakasamhita with English Translation by Bhagwandasha R.K. Sharma),Chikitsa sthana 17/64, Volume IV, II Edition, Chowkamba Sanskrit Series Office, Varanashi, pp. 117-125.

13. Gangadhar, CharakaSamhita, Part IV, 1st Edition, 1999, Chikitsa sthan 17/63-64 Chaukamba Orientalia, Varanasi, pp. 3002 to 3032.

14. Agnivesha (2000), Charakasamhita with English Translation by Bhagwandasha R.K. Sharma), Chikitsa sthana 16/11, Volume IV, II Edition, Chowkamba Sanskrit Series Office, Varanashi, pp. 101-102

15. Yogratnakar, Vidyotini Hindi Commentary, Vaidya Lakshmipati Sastri, Chaukhambha Sanskrit Sansthan, 5th edition: 1993/435-436

16. Govindadas, BhaishajyaRatnavali, 13th Edition, 1999. Editor Shashri R.D., Bhaishajya Ratnavali, 16/132-134, Chaukamba Sanskrit Bhavana, Varanasi, pp. 329 to 339.

17. Agnivesha (2000), Charakasamhita with English Translation by Bhagwandasha R.K. Sharma), Chikitsa sthana 17/8, Volume IV, II Edition, Chowkamba Sanskrit Series Office, Varanashi, pp. 117-125

18. Agnivesha (2000), Charakasamhita with English Translation by Bhagwandasha R.K. Sharma), Chikitsa sthana 17/45, Volume IV, II Edition, Chowkamba Sanskrit Series Office, Varanashi, pp. 117-125

19. Chakrapani (1994), Charakasamhita, Edition IV, Editor, Vaidya JadavajiTrikamji Acharya, Chikitsa sthana 17/45, Chaukamba Sanskriti Sansthan Publisher, Varanasi, pp. 533-539

20. Chakrapani (1994), Charakasamhita, Edition 
IV, Editor, Vaidya JadavajiTrikamji Acharya, Chikitsa sthana 17/149, Chaukamba Sanskriti Sansthan Publisher, Varanasi, p-539.

21. Agnivesha (2000), Charakasamhita with
English Translation by Bhagwandasha R.K. Sharma), Chikitsa sthana 17/121, Volume IV, II Edition, Chowkamba Sanskrit Series Office, Varanashi, pp. 130 